\title{
Evaluation of Ecophysiological Indices of Colocasia esculenta L. Schott along Elebere-Emeyal-Otuoke Road in Bayelsa State, Nigeria
}

\section{*1ETUKUDO Mbosowo M, 2UDO Joseph I and 3IHIMIKAIYE Samuel}

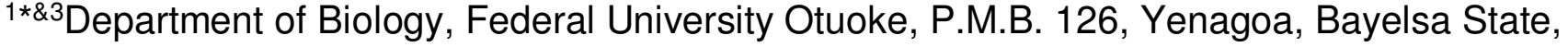 \\ Nigeria. \\ ${ }^{2}$ Department of Plant Science and Biotechnology, University of Port Harcourt, River state, \\ Nigeria.
}

Article No.: 103116196

Type: Research

DOI: 10.15580/GJBS.2016.5.103116196

Submitted: $31 / 10 / 2016$

Accepted: 07/11/2016

Published: 21/11/2016

*Corresponding Author

Etukudo Mbosowo M

E-mail: mbosombosowo @yahoo.com Phone: +2347032448796

\section{Keywords:}

Eco-physiological, Colocasia esculenta, Elebere-Emeyal-Otuoke road, Nigeria
Eco-physiological parameters of Colocasia esculenta Schott was examined along Elebere-Emeyal- Otuoke road in Bayelsa State, Nigeria. Plant (leaf of Colocasia esculenta) and soil samples were randomly collected from the road side and remote area in the study area. Five (5) sampling units were randomly choosen along the road side $\left(L_{1}, L_{2}, L_{3}, L_{4}\right.$ and $L_{5}$ ) while a corresponding five (5) sampling units were randomly choosen at the remote area $\left(P_{1}, P_{2}, P_{3}, P_{4}\right.$ and $\left.P_{5}\right)$ in the study area. Leaf of test crop and soil samples were collected at $15 \mathrm{~m}$ away from the express road for $L_{1}, L_{2}, L_{3}, L_{4}$ and $L_{5}$ sampling locations, while those for remote area, $P_{1}, P_{2}, P_{3}, P_{4}$ and $P_{5}$ sampling locations were collected at $15 \mathrm{~km}$ from the express road. Five replicates were maintained for each treatment using randomized complete block design. The $\mathrm{pH}$ values of experimental soils were more acidic at the road side than the remote area sampling locations. The soil organic matter, total nitrogen, available phosphorus, magnesium and potassium were significantly $(p<0.05)$ higher at the remote area than the road side sampling locations. In addition, the heavy metal (zinc, copper, cadmium, iron and lead) contents in soils at the road side were comparatively higher than those at the remote area sampling locations. This study suggests that appropriate pollution management measures should be employed in handling and disposal of contaminated materials at construction sites around cultivated lands. 


\section{INTRODUCTION}

Cultivated plants growing on farm lands located within road sides are prone to environmental disturbances such as heavy metal pollution by road construction activities and emission of toxic gases by vehicles (Etukudo et al. 2015; Nabulo et al. 2008). Although, civilization has been a phenomenal activity, rapid industrialization has also generated changes in soil physico- chemical properties due to pollution (Greenword, 2000; Moeller et al. 2008). In consequence, hazardous chemicals can enter into human food chain from soil to water, disturb the biogeochemical process and finally lead to toxicity effects on both plants and animals (Anoliefo, 2005; Baker et al. 2000). Environmental disturbances resulting from mining and road construction activities have been shown to constitute a major threat to environmental quality (Adepoju, 2002). Trace metals have been reported to be essential in plants nutrition, however, plants growing in an environment with excessive accumulation of trace metals pose serious risks to human health when such plants based food stuffs are consumed (Wang et al. 2008; Nabulo et al. 2008). It is known that metals may reduce the availability of nutrients to plants when present in a high concentration in soils as well as affect biological processes such as litter decomposition, soil respiration and nitrogen mineralization and the activities of key microorganisms (Bruijnzeel, 2004).

Colocasia esculenta L. Schott commonly known as cocoyam belongs to the Family Araceae (Taha, 2003). It is an erect perennial herb up to $2 m$ tall, which is mostly grown as an annual food crop. Cocoyam is a vegetable with vast potentials in terms of its leaves as leafy vegetable and the corms as relish (Matsuda and Nawata, 2002; FAO, 1996). Its corm is often utilized as one of the major carbohydrate food sources for human and animals as well as for industrial purposes (FAO, 1996). This valuable crop is also considered as an excellent multipurpose food crop for subsistence agriculture and home gardeners (Ivancic and Lebot, 2002; Taha, 2003).

This project becomes increasingly important due to the poor topography terrains that characterize the study area coupled with other prevailing environmental problems such as flooding, and intense riverine setting which requires heavy construction works. In consequence, this may affect eco-physiological parameters with deleterious impacts on the growth and development of biodiversity of plant species in the study area. The development of effective conservation strategies for plant species through regular ecological sampling in the study area requires the acquisition of baseline information, which is one the major objectives of this research. Therefore, this study was carried out to assess the eco-physiological parameters of Colocasia esculenta in the study area.

\section{MATERIAL AND METHODS}

\section{Study Area}

This study was carried out along Elebele - EmeyalOtuoke road between the month of March to June, 2016. Elebele, Emeyal and Otuoke are local communities in Ogbia Local Government Area of Bayelsa State, Nigeria. Ogbia is located at coordinates of $4^{\circ} 47^{\prime} \mathrm{N}$ and $6^{\circ} 20^{\prime} \mathrm{E}$. The major source of livelihood for the inhabitants are fishing and farming. Bayelsa State has a riverine terrain and lies in the heaviest rainfall area of Nigeria with a mean minimum monthly temperature ranging from $25^{\circ} \mathrm{C}$ to $31^{\circ} \mathrm{C}$ (Niger Delta Source, 2014).

\section{Collection of Samples}

Plant (leaf of Colocasia esculenta) and soil samples were randomly collected from the road side and remote area in the study area. Five (5) sampling units were randomly choosen along the road side $\left(\mathrm{L}_{1}, \mathrm{~L}_{2}, \mathrm{~L}_{3}, \mathrm{~L}_{4}\right.$ and $L_{5}$ ) while a corresponding five (5) sampling units were randomly choosen at the remote area $\left(\mathrm{P}_{1}, \mathrm{P}_{2}, \mathrm{P}_{3}, \mathrm{P}_{4}\right.$ and $P_{5}$ ) in the study area. Leaf of test crop and soil samples were collected at $15 \mathrm{~m}$ away from the express road for $L_{1}, L_{2}, L_{3}, L_{4}$ and $L_{5}$ sampling locations, while those for remote area, $P_{1}, P_{2}, P_{3}, P_{4}$ and $P_{5}$ sampling locations were collected at $15 \mathrm{~km}$ from the express road. Five replicates were maintained for each treatment using randomized complete block design.

\section{Analysis of Soil Samples}

Soil samples $(0-15 \mathrm{~cm}$ depth) were collected from the study site, and standard procedures (A.O.A.C, 1999) were used to analyse the soil chemical properties.

\section{Analysis of Plant Samples}

The method of Ano et al. (2007) was used for analysis of plant samples. Leaf samples of Colocasia esculenta were washed several times with water and rinsed with distilled water. They were placed in polybags. They were dried in an oven maintained at $60^{\circ} \mathrm{C}$ to a constant weight, macerated to powder, and stored in sample bottles for analysis. The powdered plant samples were oven dried at $105^{\circ} \mathrm{C}$ for 2 hours, $1.0 \mathrm{~g}$ weighed into a platinum crucible and placed in a muffle furnace maintained at $400^{\circ} \mathrm{C}$. Ashing of powdered plant materials was maintained for 5 hours followed by dissolving with $10 \mathrm{~cm}^{3}$ of $1 \mathrm{M} \mathrm{HCL}$. The solution obtained was filtered through Whatman No. 1 filter paper into $50 \mathrm{~cm}^{3}$ volumetric flask and made up to the required mark with distilled deionized water. The required reagents for analytical experiment were used, and contents of heavy metals in the solution were 
determined using Atomic Absorption Spectrophotometer (AAS) of Unicam Model.

\section{Statistical Analysis}

The data generated from this study was assessed using Analysis of variance (ANOVA) and differences in the means were tested using Least Significant Differences (LSD) at probability level of 5\% (Ogbeibu, 2005; Obi, 2002).

\section{RESULTS AND DISCUSSION}

The chemical properties of experimental soils are presented (Table 1). The $\mathrm{pH}$ values of experimental soils were more acidic at the road side than the remote area sampling locations. The soil organic matter was significantly $(P<0.05)$ higher at the remote area than the road side sampling locations (Table 1). Other soil parameters such as total nitrogen, available phosphorus, magnesium and potassium were significantly $(P<0.05)$ higher at the remote area than the road side sampling locations (Table 1). In addition, the heavy metal (zinc, copper, cadmium, iron and lead) contents in soils at the road side were comparatively higher than those at the remote area sampling locations (Table 1). The variations in soil chemical properties between the road side and remote area sampling locations as indicated in this study may be attributed to differences in prevailing ecological conditions and environmental disturbances, together with the cultural practices of a given site. The soil is a medium for plant growth, hence its physiological properties affect the nutrients availability, absorption as well as plant growth and development (Mckenzie, 2003; Chandra, 2005). Environmental quality in soil, air, and water has been shown to be seriously threatened and negatively altered due to anthropogenic influence such as mining and road construction (Adepoju, 2002 ). Heavy metals accumulations as well as dust particles have been reported to contribute to the reduction of soil $\mathrm{pH}$ as well as deterioration of soil structure and organic matter (Agbede, 2009; Ano et al. 2007). Although, the present level of heavy metals in soils and test plant tissues as indicated in this study were within the internationally recommended levels for crop tolerance in agricultural soils (Ewers, 1991; ICRCL, 1997), heavy metal contamination of soil has serious negative impacts on plant growth and development (Udo et al. 2013).

Table 1: Chemical Properties of Experimental Soils at the Study Sites

\begin{tabular}{|c|c|c|c|c|c|c|c|c|c|c|}
\hline \multirow{2}{*}{$\begin{array}{l}\text { SOIL } \\
\text { PARAMETERS }\end{array}$} & \multicolumn{10}{|c|}{ SAMPLING LOCATIONS } \\
\hline & L1 & L2 & L3 & L4 & L5 & P1 & P2 & P3 & P4 & P5 \\
\hline $\mathrm{pH}$ & $\begin{array}{l}4.62 \pm \\
0.22\end{array}$ & $\begin{array}{l}4.72 \pm \\
0.14\end{array}$ & $\begin{array}{l}4.63 \pm \\
0.35\end{array}$ & $\begin{array}{l}4.70 \pm \\
0.27\end{array}$ & $\begin{array}{l}4.75 \pm \\
0.31\end{array}$ & $\begin{array}{l}5.22 \pm \\
0.21\end{array}$ & $\begin{array}{l}5.30 \pm \\
0.43\end{array}$ & $\begin{array}{l}5.24 \pm \\
0.56\end{array}$ & $\begin{array}{l}5.40 \pm \\
0.33\end{array}$ & $\begin{array}{l}5.35 \pm \\
0.30\end{array}$ \\
\hline $\begin{array}{l}\text { Organic matter } \\
\text { (\%) }\end{array}$ & $\begin{array}{l}1.92 \pm \\
0.21\end{array}$ & $\begin{array}{l}2.06 \pm \\
0.11\end{array}$ & $\begin{array}{l}1.87 \pm \\
0.23\end{array}$ & $\begin{array}{l}1.72 \pm \\
0.15\end{array}$ & $\begin{array}{l}2.09 \pm \\
0.43\end{array}$ & $\begin{array}{l}2.26 \pm \\
0.10\end{array}$ & $\begin{array}{l}2.35 \pm \\
0.45\end{array}$ & $\begin{array}{l}2.32 \pm \\
0.30\end{array}$ & $\begin{array}{l}2.37 \pm \\
0.48\end{array}$ & $\begin{array}{l}2.30 \pm \\
0.39\end{array}$ \\
\hline Total N (\%) & $\begin{array}{l}2.07 \pm \\
0.55\end{array}$ & $\begin{array}{l}2.14 \pm \\
0.43\end{array}$ & $\begin{array}{l}2.02 \pm \\
0.13\end{array}$ & $\begin{array}{l}2.04 \pm \\
0.39\end{array}$ & $\begin{array}{l}2.06 \pm \\
0.24\end{array}$ & $\begin{array}{l}2.60 \pm \\
0.21\end{array}$ & $\begin{array}{l}2.47 \pm \\
0.67\end{array}$ & $\begin{array}{l}2.56 \pm \\
0.20\end{array}$ & $\begin{array}{l}2.49 \pm \\
0.58\end{array}$ & $\begin{array}{l}2.36 \pm \\
0.44\end{array}$ \\
\hline Avail. P (\%) & $\begin{array}{l}1.47 \pm \\
0.10\end{array}$ & $\begin{array}{l}1.38 \pm \\
0.34\end{array}$ & $\begin{array}{l}1.42 \pm \\
0.16\end{array}$ & $\begin{array}{l}1.50 \pm \\
0.33\end{array}$ & $\begin{array}{l}1.52 \pm \\
0.59\end{array}$ & $\begin{array}{l}2.94 \pm \\
0.38\end{array}$ & $\begin{array}{l}3.06 \pm \\
0.79\end{array}$ & $\begin{array}{l}3.12 \pm \\
0.23\end{array}$ & $\begin{array}{l}3.09 \pm \\
0.42\end{array}$ & $\begin{array}{l}3.17 \pm \\
0.46\end{array}$ \\
\hline $\mathrm{Ca}(\mathrm{mg} / 100 \mathrm{~g})$ & $\begin{array}{l}3.02 \pm \\
0.90\end{array}$ & $\begin{array}{l}3.09 \pm \\
1.20\end{array}$ & $\begin{array}{l}3.16 \pm \\
1.02\end{array}$ & $\begin{array}{l}3.12 \pm \\
0.40\end{array}$ & $\begin{array}{l}3.20 \pm \\
0.34\end{array}$ & $\begin{array}{l}4.20 \pm \\
0.53\end{array}$ & $\begin{array}{l}4.32 \pm \\
0.26\end{array}$ & $\begin{array}{l}4.46 \pm \\
0.54\end{array}$ & $\begin{array}{l}4.27 \pm \\
0.65\end{array}$ & $\begin{array}{l}4.38 \pm \\
0.66\end{array}$ \\
\hline $\mathrm{Mg}(\mathrm{mg} / 100 \mathrm{~g})$ & $\begin{array}{l}2.07 \pm \\
0.43\end{array}$ & $\begin{array}{l}2.01 \pm \\
0.56\end{array}$ & $\begin{array}{l}2.09 \pm \\
0.35\end{array}$ & $\begin{array}{l}2.12 \pm \\
0.50\end{array}$ & $\begin{array}{l}2.18 \pm \\
0.42\end{array}$ & $\begin{array}{l}3.16 \pm \\
0.27\end{array}$ & $\begin{array}{l}3.20 \pm \\
0.58\end{array}$ & $\begin{array}{l}3.19 \pm \\
0.11\end{array}$ & $\begin{array}{l}3.26 \pm \\
0.32\end{array}$ & $\begin{array}{l}3.22 \pm \\
0.45\end{array}$ \\
\hline $\mathrm{K}(\mathrm{mg} / 100 \mathrm{~g})$ & $\begin{array}{l}1.30 \pm \\
0.37\end{array}$ & $\begin{array}{l}1.34 \pm \\
0.22\end{array}$ & $\begin{array}{l}1.27 \pm \\
0.46\end{array}$ & $\begin{array}{l}1.24 \pm \\
0.65\end{array}$ & $\begin{array}{l}1.22 \pm \\
0.42\end{array}$ & $\begin{array}{l}1.62 \pm \\
0.40\end{array}$ & $\begin{array}{l}1.67 \pm \\
0.34\end{array}$ & $\begin{array}{l}1.70 \pm \\
0.66\end{array}$ & $\begin{array}{l}1.50 \pm \\
0.28\end{array}$ & $\begin{array}{l}1.54 \pm \\
0.37\end{array}$ \\
\hline $\mathrm{Zn}(\mathrm{mg} / 100 \mathrm{~g})$ & $\begin{array}{l}1.72 \pm \\
0.42\end{array}$ & $\begin{array}{l}1.67 \pm \\
0.48\end{array}$ & $\begin{array}{l}1.62 \pm \\
0.91\end{array}$ & $\begin{array}{l}1.64 \pm \\
0.87\end{array}$ & $\begin{array}{l}1.60 \pm \\
0.21\end{array}$ & $\begin{array}{l}0.16 \pm \\
0.24\end{array}$ & $\begin{array}{l}0.14 \pm \\
0.26\end{array}$ & $\begin{array}{l}0.12 \pm \\
0.28\end{array}$ & $\begin{array}{l}0.17 \pm \\
0.29\end{array}$ & $\begin{array}{l}0.11 \pm \\
0.21\end{array}$ \\
\hline $\mathrm{Cu}(\mathrm{mg} / 100 \mathrm{~g})$ & $\begin{array}{l}1.20 \pm \\
0.25\end{array}$ & $\begin{array}{l}1.25 \pm \\
0.26\end{array}$ & $\begin{array}{l}1.26 \pm \\
0.16\end{array}$ & $\begin{array}{l}1.22 \pm \\
0.24\end{array}$ & $\begin{array}{l}1.18 \pm \\
0.88\end{array}$ & $\begin{array}{l}0.34 \pm \\
0.31\end{array}$ & $\begin{array}{l}0.37 \pm \\
0.64\end{array}$ & $\begin{array}{l}0.30 \pm \\
0.45\end{array}$ & $\begin{array}{l}0.34 \pm \\
0.32\end{array}$ & $\begin{array}{l}0.36 \pm \\
0.74\end{array}$ \\
\hline $\mathrm{Cd}(\mathrm{mg} / 100 \mathrm{~g})$ & $\begin{array}{l}1.50 \pm \\
0.77\end{array}$ & $\begin{array}{l}1.59 \pm \\
0.21\end{array}$ & $\begin{array}{l}1.54 \pm \\
0.43\end{array}$ & $\begin{array}{l}1.49 \pm \\
0.32\end{array}$ & $\begin{array}{l}1.53 \pm \\
0.21\end{array}$ & $\begin{array}{l}0.22 \pm \\
0.05\end{array}$ & $\begin{array}{l}0.24 \pm \\
0.02\end{array}$ & $\begin{array}{l}0.18 \pm \\
0.03\end{array}$ & $\begin{array}{l}0.20 \pm \\
0.02\end{array}$ & $\begin{array}{l}0.25 \pm \\
0.05\end{array}$ \\
\hline Fe (mg/100g) & $\begin{array}{l}1.37 \pm \\
0.93\end{array}$ & $\begin{array}{l}1.34 \pm \\
0.83\end{array}$ & $\begin{array}{l}1.42 \pm \\
0.32\end{array}$ & $\begin{array}{l}1.30 \pm \\
0.23\end{array}$ & $\begin{array}{l}1.36 \pm \\
0.21\end{array}$ & $\begin{array}{l}0.12 \pm \\
0.03\end{array}$ & $\begin{array}{l}0.16 \pm \\
0.01\end{array}$ & $\begin{array}{l}0.11 \pm \\
0.02\end{array}$ & $\begin{array}{l}0.18 \pm \\
0.03\end{array}$ & $\begin{array}{l}0.14 \pm \\
0.03\end{array}$ \\
\hline $\mathrm{Pb}(\mathrm{mg} / 100 \mathrm{~g})$ & $\begin{array}{l}1.12 \pm \\
0.15\end{array}$ & $\begin{array}{l}1.14 \pm \\
0.33\end{array}$ & $\begin{array}{l}1.10 \pm \\
0.21\end{array}$ & $\begin{array}{l}1.17 \pm \\
0.33\end{array}$ & $\begin{array}{l}1.16 \pm \\
0.37\end{array}$ & $\begin{array}{l}0.09 \pm \\
0.02\end{array}$ & $\begin{array}{l}0.07 \pm \\
0.01\end{array}$ & $\begin{array}{l}0.08 \pm \\
0.03\end{array}$ & $\begin{array}{l}0.04 \pm \\
0.01\end{array}$ & $\begin{array}{l}0.02 \pm \\
0.01\end{array}$ \\
\hline
\end{tabular}

Mean \pm standard error from 5 replicates 
Table 2: Heavy Metal Contents in Leaf of Colocasia esculenta at the Study Sites

\begin{tabular}{|l|l|l|l|l|l|l|l|l|l|l|}
\hline \multirow{2}{*}{$\begin{array}{l}\text { HEAVY } \\
\text { METALS }\end{array}$} & \multicolumn{7}{|c|}{ SAMPLING LOCATIONS } \\
\cline { 2 - 10 } & L1 & L2 & L3 & L4 & L5 & P1 & P2 & P3 & P4 & P5 \\
\hline Zn (mg/100g) & $0.73 \pm$ & $0.76 \pm$ & $0.79 \pm$ & $0.82 \pm$ & $0.74 \pm$ & $0.02 \pm$ & $0.08 \pm$ & $0.02 \pm$ & $0.04 \pm$ & $0.05 \pm$ \\
& 0.02 & 0.08 & 0.02 & 0.07 & 0.03 & 0.01 & 0.06 & 0.01 & 0.02 & 0.02 \\
\hline Cu (mg/100g) & $0.41 \pm$ & $0.43 \pm$ & $0.40 \pm$ & $0.46 \pm$ & $0.42 \pm$ & $0.10 \pm$ & $0.09 \pm$ & $0.07 \pm$ & $0.08 \pm$ & $0.04 \pm$ \\
& 0.05 & 0.02 & 0.15 & 0.12 & 0.10 & 0.02 & 0.04 & 0.02 & 0.03 & 0.02 \\
\hline Cd (mg/100g) & $0.34 \pm$ & $0.30 \pm$ & $0.33 \pm$ & $0.36 \pm$ & $0.31 \pm$ & $0.02 \pm$ & $0.01 \pm$ & $0.03 \pm$ & $0.02 \pm$ & $0.01 \pm$ \\
& 0.06 & 0.11 & 0.13 & 0.10 & 0.02 & 0.01 & 0.01 & 0.01 & 0.01 & 0.01 \\
\hline Fe (mg/100g) & $0.52 \pm$ & $0.56 \pm$ & $0.50 \pm$ & $0.52 \pm$ & $0.54 \pm$ & $0.03 \pm$ & $0.02 \pm$ & $0.01 \pm$ & $0.03 \pm$ & $0.02 \pm$ \\
& 0.13 & 0.03 & 0.10 & 0.12 & 0.04 & 0.01 & 0.01 & 0.01 & 0.01 & 0.01 \\
\hline Pb (mg/100g) & $0.20 \pm$ & $0.23 \pm$ & $0.26 \pm$ & $0.21 \pm$ & $0.27 \pm$ & $0.01 \pm$ & $0.02 \pm$ & $0.03 \pm$ & $0.02 \pm$ & $0.01 \pm$ \\
& 0.15 & 0.13 & 0.13 & 0.10 & 0.07 & 0.01 & 0.01 & 0.01 & 0.01 & 0.01 \\
\hline
\end{tabular}

Mean \pm standard error from 5 replicates

In this study, the heavy metal (zinc, copper, cadmium, iron and lead) contents found in leaf of test crop at the road side were relatively higher than that of the remote area sampling locations (Table 2). Heavy metals are of serious concern due to their persistence in the environment, and cannot be destroyed biologically but are only transformed from one oxidation state or organic complex to another (Raskin et al. 1994; Udo et al. 2013). Similarly, high concentration of heavy metal in soil has been reported to negatively affect crop growth, as these metals interfere with metabolic functions in plants such as physiological and biochemical processes, inhibition of photosynthesis, and respiration and degeneration of all organelles, even leading to death of plants (Turer et al. 2003; Inoni et al. 2006).

\section{CONCLUSION}

This study showed that elevated levels of heavy metals together with low mineral nutrients and organic matter were found in soils and leaf tissues of test crop along the road side sampling locations comparable with soils at remote area. This study suggests that appropriate pollution management measures should be employed in handling and disposal of contaminated materials at construction sites around cultivated lands.

\section{COMPETING INTEREST}

There was no conflict of interest among the three authors.

\section{AUTHORS' CONTRIBUTIONS}

This work was carried out in collaboration between all authors. Author MME designed the study, wrote the protocol and wrote the first draft of the manuscript. Author JIU supervised the work and revised the final manuscript. Author SL managed the literature searches. All authors read and approved the final manuscript.

\section{ACKNOWLEDGEMENTS}

We wish to appreciate the contributions from Mr. Sunday Okpata, Department of Biology, Mr. Isaac Udo Isaac, the Senior Technologist, Department of Chemistry, and Mr Awolabi Akeem, Department of Biochemistry, Faculty of Science, Federal University Otuoke, Bayelsa State. We also acknowledge all authors whose works have been cited as well as incorporated into the references of this paper.

\section{REFERENCES}

Adepoju SO (2000). Effect of coal extraction on water, soil acidty and organic matter of Igun. Nigerian Journal of Engineering. 1: 30-33.

Agbede OO (2009) Understanding Soil and Plant Nutrition. Nigeria Salmon Press and Co. Nigeria Ltd. $20-60$.

Al- Azab M, El-Shorbagy W and Al-Ehias S (2005). Oil pollution and its environmental impact in the Arabian Gulf Region; Measurement of photosynthesis and respiration in oil polluted soil. Books.goggle.com.nglbooks? isbn $=0444520600$.

Anoliefo CO (2006). Introductory tropical plant biology. Nigeria: Uniben Press, 257- 362.

Ano AO, Odoemelam SA and Ekwueme PO (2007). Lead and cadmium levels in soils and cassava (Manihot esculenta Crantz) along Enugu- Port Harcourt express way in Nigeria.Electronic Journal of Environmental, Agricult ural and Food Chemistry. 6(5): 2024 - 031.

A.O.AC. (1999). Association of Official Analytical Chemist. Methods of analysis (16h Edition), Washington DC., U.S.A.

Baker AJM, McGrath SP and Reeves RD (2000). Metal Hyper accumulator Plants. A Review of the Ecology and Physiology of a Biological 
Resource for Phytoremediation of metal- polluted soils. In: Terry N, Banuelos G, Editors. Phytoremediation of Contaminated Soil and Water. Boca Raton: Lewis Publishers. 85-108.

Bruinzeel AT (2004). Mining processes and effects on the Environment. Nature and Science, 4, 16-20

Chandra K (2005). Production and quality control of organic inputs; A 10 day training programme on production and quality control of organic inputs of Kottayam, Kerala Regional Centre of organic farming- Herbbal, Banglaore, 24, 1-46.

Etukudo MM, Okereke IJ and Ekpo EJ (2015). Evaluation of heavy metal profiles in Telfairia occidentalis Hook and soil along Abak-Oruk Anam Ukanafun road in Akwa Ibom State of Nigeria. Inter. Journ. R. Sc. Res. 15 (2), 254- 258.

Ewers U (1991). Standards, guidelines and legislative regulations concerning metals and compounds. In Merian E. Edn. Metals and their compounds in the Environment: occurrence, analysis and biological relevance. Weinheim: $\mathrm{VCH}$.

FAO (1996). The state of the world's plant genetic resources for food and agriculture organization, Rome, Italy.

Greenword JJD (2000). Basic techniques in population studies. In: William J. Sutherland (eds), Ecological Census Techniques. United Kingdom, Cambridge University Press. 12-105.

Interdepartmental Committee for the Redevelopment of Contaminated Land (ICRCL) (1997). Guidance on the assessment and redevelopment of contaminated land. $2^{\text {nd }}$ Ed. Department of Environment, London. Paper\#59/83.

Inoni OE, Omotor DG, and Adun FN (2006). The effect of oil spillage on crop yield and farm income in Delta State, Nigeria. Central European Journal of Agriculture. 7(1), 41- 48.

Ivancic $A$ and Lebot $V$ (2002). The genetics and breeding of taro. Librairie du GRAD, Montpellier, France.

Mckenzie RH (2003). Soil ph and plant nutrients. Alberta agricultural, food and rural development, Alberta.
Moeller J, Gaarn H, Steckel T, Wedebye EB, Westermann P (2008). Environmental sciences, biodegradation, argumentation, diesel fuels, soils contamination. Bulletin of Environmental Contamination and Toxicology, 96 (6), 913- 918.

Nabulo G, Origa OH, Nasinyama GW, Cole D (2008). Assessment of $\mathrm{Zn}, \mathrm{Cu}, \mathrm{Pb}$ and $\mathrm{Ni}$ contamination in wetland sois and plants in the Lake Victoria basin. International Journal of Environmental Science and Technology, 5 (1), 65-74.

Niger Delta Source: Bayelsa State. (2014). http://nigeriadeltasource.com/bayelsa

Obi 1U (2002). Statistical Methods of Detecting Differences Between Treatment Means and Research Methodology Issues in Laboratory and Field Experiments. Nigeria, AP Express Publishers Limited.

Ogbeibu AE (2005). Biostatistics: A practical approach to research and data handling. Mindex Publishing Company Limited, Benin.

Raskin I, Nanda PBA, Dushenkor S and Salt DE (1994). Bioconcentration of heavy metals by plants. Current Opinion in Biotechnology.1994; 5(1): 285-290.

Taha RT (2003). Colocasia esculenta L. Schott. In Lemmens, RHMJ \& Bunyapraphatsara $n$ (Edtors). Plant resources of south East Asia No 12(3). Medicinal and poisonous plants 3. Backhuys Publishers, leiden, Netherlands, 130-131.

Turer DG and Maynard BJ (2003). Heavy metal contamination in highway soils. Comparison of Corpus Christi, Texas and Cincinnati, Ohio shows organic matter is key to mobility. Clean Technology Environment Policy. 4, 235- 245.

Udo JI, Etukudo MM and Nwachukwu EO (2013). Evaluation of Five Weedy Species for Potential Phytoremediation of Heavy Metals in Soil Contaminated with Crude Oil in the Nigerian Coastal Region. Nigerian Journal of Botany, 26 (2), 297-306

Wang Q, Cui Y and Dong Y (2008). Phytoremediation of polluted waters potential and prospects of wetland plants. Acta Biotechnology. No1, 22(12), $199-208$. 